ISSN: 1641-4713; e-ISSN: 2081-1160

DOI: https://doi.org/10.36551/2081-1160.2020.25.81-102

\title{
Proyectos Comunitarios in Havana: Tourism as Resource for Grassroots Development in Late Socialist Cuba
}

\author{
Proyectos comunitarios en la Habana: turismo como recurso \\ para desarrollo desde las bases en la Cuba del socialismo tardío
}

\author{
Oskar Stefan Lubiński \\ Institute of Ethnology and Cultural Anthropology, University of Warsaw, Poland \\ ORCID ID: https://orcid.org/0000-0002-9195-4971 \\ E-mail: oskar.s.lubinski@gmail.com
}

Recepción: 27.11.2019

Aprobación: 15.04.2020

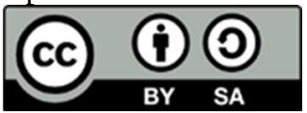

\begin{abstract}
The aim of this article is to consider intersections between tourism-oriented economies and the politics of infrastructure and community development in a (late) socialist country. I argue that although tourism is usually considered a mechanism that deepens existing inequalities and creates new ones, in the context of late socialist Cuba it becomes a resource that the creation of new ideas for community development and brings attention to various social issues. My research builds on a rich body of work that considers the impact of touristic transformations in Cuba while linking it to the critical reflection on Cuban revolutionary ideology and strategies of community engagement.
\end{abstract}

Keywords: Cuba, tourism, development, community projects, informal settlements

Resumen: El objetivo de este artículo es analizar las intersecciones entre economías orientadas al turismo y las políticas de desarrollo local y de infraestructuras en el contexto de un país del socialismo (tardío). Mi propósito es demostrar cómo turismo, considerado en general como un mecanismo de profundizar las desigualdades sociales y crear desigualdades nuevas, se utiliza como una herramienta para promover el desarrollo comunitario y atraer atención a varios problemas sociales en el contexto del socialismo tardío en Cuba. Mi investigación está basada en una literatura extensa que considera el impacto de las transformaciones turísticas en Cuba, pero al mismo tiempo, las confronta con una reflexión crítica sobre la ideología de la revolución cubana y estrategias de trabajo comunitario.

Palabras clave: Cuba, turismo, desarrollo, proyectos comunitarios, asentamientos informales 
Los Pocitos, located in the western part of Havana in Marianao district, can be a misleading place. Its name refers to clear springs that flow into the river Quibu. Today, it is a peripheral district of Havana, still full of picturesque residences, remains of former public baths, a monumental bridge across the river and green riverbanks that elude to its former glory. In the nineteenth century it served as a summer residence for rich habaneros who came there for clear springs and good air. Further down the district there is a sports stadium where many practice field hockey which came to be regarded as a local sport and helped build sport careers for some of the inhabitants. However, these same green riverbanks host a growing informal settlement that dates back to the 1940s. From the evenly ordered streets one suddenly enters a difficult to navigate labyrinth of narrow passages between small houses, bustling with people going about their informal businesses (such as selling perfume, foodstuffs, etc.) or spending time playing dominoes and keeping away from the tropical heat in the little shade provided by the existing infrastructure. The local community is also deeply religious with a significant presence of Afro-Cuban religions: Abakúa, Palo monte, and Santería. It counts with around a dozen Abakúa temples and at any time of the day one can come across a person dressed in white which means they are going through the process of hacerse santo - initiation to the Santería.

Informal settlements in Cuba are known as places of marginality and poverty. At the same time, due to the lack of infrastructure, these communities suffer from limited access to potable water and from the pollution caused by the lack of garbage disposal facilities. Pollution also affects water sources as it enters the river around which the settlement is developed. The legal status of the inhabitants, who are officially registered outside the province of Havana, makes it difficult for them to find formal employment in the capital or have access to food provisions that are tied to the official place of living.

During the years there have been several initiatives aimed at collaborating with informal settlers to improve their living conditions through means of sustainable development; one of the most recent ones is Proyecto Akokán los Pocitos that seeks to capitalize on tourism to Cuba and use the district's uniqueness to improve its economy and thus help create opportunities to overcome marginalization. The project started in 2016 as a university extension project from Colegio Universitario de San Cristobal, a mechanism designed to allow the use of university knowledge in resolving community issues. With time however, Proyecto Akokán became a separate entity. As explained by the leader and initiator of the Akokán, Michael, separation offered him more autonomy and better 
opportunities for developing of project activities. The aims of the project are to improve life quality of the inhabitants of the settlement and minimize the negative impact of social, economic, and environmental factors. It offers a space for a library and various workshops, especially dedicated to children, as well as entails other activities carried out within the informal settlement of los Pocitos. In order to assure funds for the project, Michael offers tours around the settlement, especially to visiting students, while his wife Deborah hosts Café Oddara where visitors come to enjoy a meal after the tour and can buy souvenirs that are produced as a result of some of the project workshops. Both the name of the project, as well as the Café refer to the Afro-Cuban heritage, as Akokán means "heart," while Oddara "everything is alright" in the Yoruba language. ${ }^{1}$

I visited the los Pocitos community and got to know Michael and Deborah, Proyecto Akokán leaders for the first time in March 2018 when doing preliminary fieldwork. In November 2018 I came to revisit the district and participate in the yearly evaluation of the community project. As it turned out, its coordinators had to readjust their plans of setting up the community center halted due to administrative difficulties. Instead of building an entire new development, they repurposed unused spaces in the urban stadium and received some other additional spaces from the municipality that required work beyond the scope allowed by the funding they had. Michael also mentioned that he changed his approach and preferred to have smaller nodes that would be closer to the community rather than a big center. He expressed frustration as the project entered into a moment of economic hardship. The limitations on travels from the United States of America imposed by the Donald Trump administration made it hard to find tour groups around the community. Up until that point, such groups had served as a main source of income. This forced everyone involved in the community project to look for other sources of revenue, that would allow the initiative to continue.

Proyectos comunitarios or community projects epitomize the transformations of the Cuban economies and the development of new grassroots engagements on the margins of state planning. Cuba has been experiencing profound changes as a result of its readjustment toward tourism in response to losing its main trade partner, the Soviet Union in the 1990s. At the time, the Cuban economy was almost entirely dependent on the subsidies from its ally. The fall of the Soviet Union thus meant a lack of fuel, food, and sanitary products and many

\footnotetext{
${ }^{1}$ During the nineteenth century significant number of slaves brought to Cuba came from Yoruba groups and Yoruba is now one of the ritual languages used within Afro-Cuban religions.
} 
other resources. Certain changes needed to be introduced to the economy, in order for the country to function. Despite readjustments, Cuba remains a socialist state with alternative views on development that may differ from other Latin American and Caribbean countries.

The aim of this article is to consider intersections between tourism-oriented economies and the politics of infrastructure and community development in a late socialist country. I argue that although tourism is usually considered a mechanism that deepens existing inequalities and creates new ones, in the context of late socialist Cuba it becomes a resource that the creation of new ideas for community development and brings attention to various social issues. My research builds up on a rich body of work that considers impact of touristic transformations in Cuba (de la Fuente, 2011; Cabezas, 2004; Hodge, 2014; Medina Lasansky, 2004) while linking it to the critical reflection on Cuban revolutionary ideology (Fernández, 2000; Gordy, 2015), and strategies of community engagement.

I analyze the dynamics behind the formation of proyectos comunitarios and the emergence of new notions of development and solidarity as a result of community work and ongoing socioeconomic changes in the country in the context of the evolution of the Cuban socialist ideology and its views on the formation and functioning of civil society. I start with the analysis of how the socialist state after the victory in the 1959 Revolution tried to reinvent Cuban society both on ideological level as well as through various social reforms. This will bring me to the economic crisis of the 1990s and the reintroduction of tourism to Cuba. I follow with an analysis of the reemergence of marginalization and social differentiation and the decay and questioning of the Cuban socialist values. Finally, I will focus on the work of community projects to repurpose the values of solidarity in the context of tourism-oriented economies and consider whether they create an alternative to the pre-existing state initiatives and models of development.

The article is based on based on the ethnographic material gathered on the community projects during two field trips realized in March-April and November-December 2018. During these trips I interviewed three of the project leaders and had around 20-30 informal conversations with different members of the community involved in the project and with several leaders of other community projects in the area of Havana. I participated in the project activities within the community of los Pocitos, in networking events with other community projects, but I also conducted English workshops for children and young adults as a way of becoming acquainted with the community and responding to their needs. 


\section{CREATING THE NEW MAN: SOCIAL MOBILIZATION AND DEVELOPMENT} DURING SOCIALISM

With the victory of the Cuban revolution in 1959, numerous reforms to remedy rampant inequalities and institutional racism that led to its eruption were introduced. Their purpose was to ensure social equality and equal access to housing, to provide education and healthcare, to eliminate poverty, and to overcome social marginalization and structural racism. Through the redistribution of land, alphabetization campaign, a universal healthcare plan, and access to education, the Cuban government managed to improve the lives of its citizens and has been recognized for its achievements worldwide.

One of the important reforms was aimed at resolving housing shortages in Havana and the rest of the country. Thanks to the redistribution of real estate and reform of the estate law as well as new developments, the revolutionary government managed to eradicate some of the biggest informal settlements (or barrios insalubres, unhealthy districts as they were called) (Segre et al., 1998: 131) within the capital. The formation of the informal settlements in Havana can be traced back to the 1940s and the 1950s when, similar to other Latin American cities, rapid industrialization forced many migrants to arrive in the cities in search of work. However, this growth was not accompanied by the development of sufficient housing infrastructure. This led to the creation of squatter settlements usually in the peripheral areas of the city. Due to housing reform, the living conditions of numerous habaneros improved. However, after initial success, in order to discourage massive migrations towards the capital, the socialist government prioritized other regions. As a matter of fact, it was the only country in Latin America that managed to considerably slow down the growth of its capital (Coyula \& Hamberg, 2005) and develop other provinces. Despite these efforts Havana retained its central character in Cuba, but the policies of discouraging migrations and lack of investments in the city eventually led to deterioration of its urban infrastructure.

The revolutionary project aimed not only at infrastructural development of Cuba but also at the moral transformations of its citizens by creating the New Man (Hombre nuevo). The idea was to negate class divisions and create a new kind of classless, unified society (Frederik, 2005) that would embody the ideals of socialism, similar to other socialist countries (Yurchak, 2005). Cubans were supposed to develop new revolutionary conscience (conciencia), and abandon the negative aspects of Cubanness, such as "chapucería (shoddiness) and blanden- 
guería (wimpiness)" (Fernández, 2000: 34). According to Damián J. Fernández the strength of the Cuban socialist state lay in the ability to mobilize its people through appealing to their passions and affective relations with the state. This was especially prominent during the first years of the Revolution. Back then, many of the initiatives were based not on the state nomenclature and bureaucracy, but rather "the programs implemented throughout the 1960s relied on 'informal institutions' (mobilization, volunteerism, the armed people, a personalistic leadership style) rather than on formal institutional procedures" (Fernández, 2000: 58). ${ }^{2}$ These policies laid the basis for grassroots social initiatives and community engagement that provided legitimacy for the Cuban state and also served as a means of dialogue between the Cuban state and its society.

The ambitious plan to improve the lives of Cubans led the state to develop a "political religion," built on religious symbolism and understood as an affective discourse, allowed thus to fuel the readiness to self-sacrifice and effort for the revolution on part of the Cuban population (Fernández, 2000: 67). Consequently, the expectations of Cubans of having a good quality of life, decent housing, and access to goods were proportional to the effort that was expected from them (Fernández, 2000: 88). The inability to achieve these goals led to development of an informal sector and disassociation between the official ideology and everyday realities of Cuba. This affected especially youth in the late 1980s and 90s who hoped for certain reforms similar to other Soviet countries and also related to the discord between formal, specialized education and salaries offered. Every time I visited Havana, I would meet former doctors who started renting houses or working as taxi drivers because, as they claimed, the salaries offered in hospitals did not allow them to make a living. Similarly, Michael who before starting the project, worked in the University of Havana as a lecturer, but in order to make ends meet and provide for his family, he also performed as a living statue in the street of Havana. He was also tired of not being able to present his ideas and innovations at the University as he felt they were blocked by tenured faculty. This feeling of being left out as the older generations continued governing, refusing to share power was also common among the youth.

In an attempt to improve and adjust to the reality of the 1980s and the ongoing changes in the Soviet Bloc, the Cuban government organized a campaign of rectificación de los errores, correction of mistakes, that on the one hand was

\footnotetext{
${ }^{2}$ These mechanisms helped facilitate the Cuban Literacy Campaign of 1961 that raised the national literacy rate to $96 \%$ and realize la zafra de los diez millones in 1970 - the campaign to produce 10 million tons of sugar in one year.
} 
aimed at removing market incentives as mechanisms of productivity, but on the other introduced decentralization and new management techniques into state enterprises (Klepak 2015: 75). This led to changing the approach of the Cuban state towards grassroots initiatives and developing dialogue with local communities. The result was the creation in 1988 of Talleres de Transformación Integral de Barrio (Workshops for the Integral Transformation of the District) as part of the efforts of the Cuban government to engage with the neighborhoods and neighborhood organizations in Havana. They consisted of multidisciplinary groups of architects, social workers and social scientists and engaged with different communities in order to improve the quality of life in the neighborhood. Although formally under the state administration, Talleres served as a space for expressing and realizing more grassroots initiatives with various effect. In some cases, such as in barrio Pogolotti, they have become model initiatives, while in other cases they were abandoned after some time due to difficulties in continuing them (Colantonio \& Potter, 2006). Formation of these Talleres and Grupo para el Desarrollo integral de la Capital (Group for Integral Development of the Capital) that coordinated their works on the city level demonstrated how Cuban state readapted itself and the ideas of development to gain more efficiency in development efforts. As top-down initiatives would oftentimes fail and not necessarily respond to community needs it created a new deliberative instrument to resolve ongoing problems within Cuban society. Many of these workshops play an essential role in community dialogue today and help in the state recognizing and supporting different community initiatives as in the case of the neighborhood of Cayo Hueso in Centro Habana (Anguelovski 2014: 99-130).

However, some situations might have proven more difficult to justify within the socialist spirit and readjustment might have contributed to a certain decay of this spirit and the ethics of the New Man. This was especially visible during the crisis of the 1990s and another readjustment of the Cuban economy that according to some led to disappearance of solidarity and collective cooperation. The following two sections will serve to describe this process: the first one will be dedicated to the crisis itself and creation of new social divisions and marginalization, while in the second I will take a closer look at the perceptions of changes in personal behavior of Cubans as a result of economic hardships. 


\section{SPECIAL PERIOD AND THE REEMERGENCE OF MARGINALIZATION}

The deep economic crisis of the 1990s is commonly known by the name Fidel Castro gave it in response to the fall of the Soviet Union - Special Period in times of Peace. Losing its main strategic and trade partner meant that Cuba would no longer receive fuel and other important resources in exchange for sugar. This implied the necessity to sell its main export product on the global markets where its price was significantly lower in comparison to what used to be offered by the Soviet Union. To make matters worse, the subsequent strengthening of the United States of America trade embargo on Cuba aimed at destabilizing its government. As such the country was experiencing severe shortages of food, personal hygiene products. Many were trying to leave the country on small self-made rafts (crisis de los balseros of 1994) while other Cubans migrated to Havana and other major cities from the interior in search of better opportunities.

Given that Cuban government does not allow for free movement of people, most of these migrations were unauthorized and carried a risk of being deported. As a consequence, newcomers did not seek housing through official means but rather squatted previously abandoned solares or built shacks - llega $y$ pon as they are called by Cubans. Solar is a type of residential building from colonial era that predominated Cuban urban spaces; usually it used to have a big empty space called solar in the entrance. As these buildings that usually hosted one family, started to be inhabited by newcomers, they divided big halls into smaller spaces for their houses. Even today the walls of these buildings carry signs of different architectural and family arrangements. The conditions of living in both cases were precarious as the city suffered from deteriorated and insufficient infrastructure. Further aggravating the situation, scarcity and state control of construction materials made maintenance of the already existing one almost impossible. To remedy living in cramped spaces of solares, their inhabitants started constructing barbacoas, additional scaffoldings that added floors between very high stories. These additions however affected ventilation and access to light, as well as put strain on buildings structures that contributed to their further deterioration and destruction (del Real \& Scarpaci, 2011).

To remedy the challenges that piled up in the 1990s, the Cuban government decided to capitalize on the island's tourist potential. Given that tourism has been regarded as one of the demons of imperialist exploitation, this step was supposed to be a temporary measure but gradually became one of the most important sectors of the economy (Colantonio \& Potter, 2006: 39). In 1994 a new Ministry 
of Tourism was formed, and not only did Cuba start exploiting its beaches for the purpose of $3 \mathrm{~S}$ tourism (Sun, sea, and sand), but also capitalized on the nation's cultural heritage. Colonialism's legacy served as an additional incentive for tourists to visit this Caribbean island, and the inclusion of the Habana Vieja district in the UNESCO World Heritage list in 1982 provided legitimacy for its promotion. As such, considerable investments were also put into the renovation of Habana Vieja so it would be transformed from a marginalized neighborhood to a place ready for receiving millions of foreigners. The well-preserved colonial architecture along the four plazas (Plaza de la Catedral, Plaza de Armas, Plaza de San Francisco de Asis, and Plaza Vieja) and Obispo street became central to the most beaten tourist track.

It was not without a reason that this formerly marginalized and poor district of Havana, yet rich in colonial heritage, came to the fore. According to D. Medina Lasansky (2004) it was also "safer" from the ideological standpoint as the Hispanic heritage was less controversial than the remains of the Imperialist period under the domination of the U.S.A. Up to that point Habana Vieja was one of the poorest and more marginalized districts of Havana partially due to years of neglect and its crumbling infrastructure. However, it rapidly became presented as a success story thanks to efforts of the Oficina de Historiador de la Ciudad de la Habana under the direction of Eusebio Leal Spengler. In 2000, six years after reopening of the Ministry of Tourism, the number of visitors to the district reached almost 2 million (Carty, 2009: 167) and has been growing ever since. The district was transformed into a tourist attraction with renovated, picturesque architecture ${ }^{3}$ luxury hotels, restaurants, museums, and artisanal shops and businesses of every sort, from souvenir stores to personalized perfume designers while the numbers of foreign tourists have been growing steadily. At the same time, the plan of renovation of the district included investing in social infrastructure and taking care of the local community (Bowman, 2015). Those who were to be evicted were offered housing in other, more peripheral areas of the city.

However, the success story of tourism came with a price as it resulted in rampant inequalities stemming from whether one had access to tourism or not. As of the 1990s, it was tourists who provided access to hard currency (as the official state salaries remained frozen and now amount to around 20 dollars a month) which gave access to better life quality. As such, many Cubans reme-

\footnotetext{
${ }^{3}$ Sometimes it was actually rebuilt from the scratch in the "colonial style" or just the facades were renovated while interiors were entirely different from the original designs of buildings (Medina Lasansky, 2004).
} 
died their lack of access to employment in this sector by engaging in informal contacts with the tourists in order to improve their economies (sometimes through sex work, street hustling or other illicit activities).

The reintroduction of tourism and certain liberalization of the economy resulted in the rise of institutional racism as it was mostly white Cubans who were employed in the tourist industry, whereas Afro-Cubans were dismissed on the bases of "indecent looks" (de la Fuente, 2011). Although the socialist government managed to guarantee access to healthcare and education, its policies of colorblindness did not eradicate culture of institutional racism, but rather moved it to private spaces. The radical socio-economic changes in Cuba in recent years simply resurfaced these issues putting the efficiency of adopted politics into question (Lievesley, 2004: 144-145). This also responded to racial imaginaries within Cuban society as it was the black population that would be associated with engaging in sex work and harassed by the Police (Cabezas, 2004).

\section{SPECIAL PERIOD AND CHANGING MORAL VALUES}

The reintroduction of tourism led to deep transformations of Cuban economies also outside of tourist areas. Difficult access to employment and insufficient wages within the state sector created a turn where informal activities or negocio (making business) led to more income than formal employment. My main research participant and one of the important figures within the community of Los Pocitos, Raiza, mentions how despite living in the settlement, she was well off with her sports scholarship and subsequent work in a state café, but as opportunities closed, she moved on to selling perfume bottles or collecting and cleaning glass bottles - a precarious and poorly paid informal work. Young adults inhabiting the community were also engaging in various informal activities - from preparing and selling home-made perfumes and reselling sweets and foodstuffs on the streets to dealing drugs. ${ }^{4}$

The rise of informality is not something that appeared on the margins or outside of the state. As the ongoing economic changes needed to be justified ideologically, the Cuban government started idealizing tourist industry and promoting individual initiative in making a living. Even now, one can see numerous bill-

\footnotetext{
${ }^{4}$ The Cuban state allows for a limited number of private businesses and in order to have one, a person needs a licencia, an official permit. As some people explained to me however, obtaining one requires having the property of the house where one intends to provide the business. This further restricts accessibility to such engagements for the inhabitants of the settlements.
} 
boards on Cuban roads that explain how tourism serves for the good of Cuban people and both government newspapers and other publications explain the role of tourism in sustaining the Cuban economy. However, the official discourse went beyond the question of tourism and introduced the idea of individual responsibility for one's wellbeing. Contrary to the speeches of Fidel Castro, his brother Raul who took over the leadership of the country underlined how socialism meant that the state provided the equality of opportunities but the rest depended on one's individual labor (Premat, 2012: 20-21). Thus, even in official discourse, Cubans were supposed to rely on their own initiative to resolver (a term that meant finding access to certain goods usually through informal or illegal means as a strategy of survival in periods of subsistence) or luchar (which literally means to fight and refers to finding a way to survive each day).

However, it was not only material deterioration that marked the Special Period, but also the questioning of the moral values of socialism and the efforts that were required on part of the citizens. As mentioned by Fernández (2000: 79): "The greatest disenchantment perhaps was not the material one ..., but the moral one, because the revolution was supposed to be, above all 'spiritual renovation of the nation." During all my stays in Havana, I had numerous conversations with people on the streets, taxi drivers, and owners of the businesses who would ask right away whether it was better in Poland during capitalism or socialism and complain about any lack of change in the recent years. Even those who idealized the revolution in its first years expressed being tired with having the same people govern the country. This disappointment could be seen on various levels, in everyday conversations with Cubans that were asking me, as a tourist, for money on the streets of Havana, as well as in cultural expressions, such as increasingly popular rap music that criticized how Cuba became a place to please tourists and not a place for Cubans (Baker, 2006) and touched upon the issues of racial and social inequalities, as well as lack of opportunities for Cuban youth in the country (Fernandes, 2003).

This new situation produced new moralities and a more individualistic ethics of everyday life. As this narrative remains one of the dominant ones about the 1990s in Cuba and what followed afterwards, I wanted to understand, how community projects are situated within it. I invited thus Michael and Deborah to talk about Proyecto Akokán. We discussed difficulties in approaching community members who were less interested in workshops and gaining knowledge but would rather focus on earning money. Deborah and Michael followed with various examples of 
individuals well situated within the community who would abuse the project for their personal gain which led to a more general reflection on Cuban society.

In my conversations with various habaneros, Special Period is marked as one of the most traumatic times in their lives. Almost everyone experienced hunger and food shortages. This led to a more individualistic mentalities and reliance on one's own effort rather than on the state provisions. One of the strongest examples of changing mentalities is questioning the validity of education as a means of earning a decent living or achieving upwards social mobility (Blum, 2011: 213). This became obvious, during my previous research on private rent houses (casas particulares) between 2014-2016. Amalia, an 18-year (at the time of the conversation) a relatively well-off daughter of the owner of casa particular in the Habana Vieja district claimed that con educación no se puede tener vida, ${ }^{5}$ where having a life meant earning an income that allows one to go out and have access to consumer goods The resurfacing of racial and class divisions was also strongly linked to these changes. The lack of opportunities for official employment as well as a lack of family abroad who could provide the remittances reinforced the already existing stereotypes. Because it was Afro-Cubans who largely benefitted from the revolutionary reforms, fewer of them left the country during the revolution. Consequently, significantly lower percentage of Cuban population migrated from Cuba after the revolution and was later able to provide sources of investment for the ones who stayed in the country (Duany, 2007). As such, Afro-Cubans lacked the social capital that would allow them to invest in businesses thanks to remittances from abroad and, at the same time, were not able to find employment in tourism which forced them to look other, informal ways of accessing hard currency.

The long-term effects of the crisis and subsequent reforms remain until this day. With the average state salary (state sector remaining the biggest employer in Cuba) that amounts roughly to 25 dollars a month this is hardly, if at all achievable, thus many professional, highly specialized jobs (such as doctors or teachers) were being abandoned in favor of engaging in tourism industry. Consequently, it is individual effort and access to tourism that guarantees success in life, but at the same time as I will argue in the following sections tourism becomes an instrument for creating and introducing community development initiatives.

\footnotetext{
${ }^{5}$ With education you can't have life.
} 


\section{RESPONDING TO NEW REALITIES AND CHANGING THE INDIVIDUALIST ETHICS}

Precarization and informalization of work, as well as a constant concern with daily issues seem to predominate in the lives of informal settlers and other marginalized communities in Havana. Proyectos comunitarios are formed precisely around these issues. One of their ideas is to provide people with instruments that will allow them to improve their living conditions and resolve the ongoing issues. In many cases, project leaders are either artists or academics who became involved in cultural animation which led to other activities. The approach to communities may differ in dependence of the background of people involved in the project and the context of the community itself. According to my experience however, numerous projects offered certain types of activities for children whose pastime due to lack of other alternatives is mostly being on the streets. However, in case of Proyecto Akokán project leaders come from outside the community which sometimes translates into difficulty in engaging community members, despite relative success with providing workshops for children. Adolescents and adults proved difficult to reach out to as they are the ones who start becoming less interested in going to school and more in gaining money. This question also arose during my interview with Michael and Deborah, and it sprung as the main difficulty when working with the community. It was mainly young people who lacked interest in education and prioritized other activities, especially those that could secure access to money.

This issue has also arisen during my fieldwork. As I was trying to engage more with the community, I proposed to provide some English classes both for children and young adults. Children would attend the workshops more or less regularly, however despite setting the date and time with youth (by consulting them and setting the time based on their expression of interest), I never had more than 4 people during the class, and after a few classes no one would attend. The reason was always similar - "I had to work," "something had come up," "I had a client" (one was a local barber and sometimes would attend the class only for 20 minutes as he would have to go to attend clients). Other times, when walking to the classroom with Raiza, we would talk to some people on the road and invite them to come. Usually they would respond "Voy ahorita," which could mean they are coming soon, but could also refer to a rather unspecified moment in the future, if ever. Raiza would tell me that they would probably not appear as we saw them for example frying tomatoes to make a salsa (to put them into bottles and sell 
them) or engaging in other activities that would provide them some income. It was thus the necessity to work and economic circumstances that took priority over participation in workshops, even if they would benefit in the long run.

Michael and Deborah talked about this issue on the level of the community. They remarked that most inhabitants come from outside of Havana and have little sense of common good and care for the city as they do not identify with it. They also mentioned how certain behaviors changed once the participants in the project started repairing parts of the local infrastructure:

D: ...nosotros lo vivimos cuando estábamos arreglando la Escalera, que lo estábamos haciendo sin el conocimiento de albañilería con las manos, no sé. Y al principio se burlaron, dijeron "ay, pero esa gente está loca." Y después ellos mismos se involucraron y comenzaron a preparar la mezcla, decir "mira, esta fórmula que están usando no es la correcta yo les arreglo." 6

It is thus the direct engagement within the community that produced a more direct reaction from it. Although workshops are provided close to it, the stadium is around 500 meters from Escalera separated by several street blocks. This impacts the efficiency of the project in creating contact with the community. It seems however that in the interpretation of the project leaders, the difficulties in collaborating with the community come from lacking the capacity to aspire as explicated by Arjun Appadurai (2004). He understands it as the cultural capacity to voice collective needs and plan for the less immediate future and project rather than constantly resolve everyday problems. The situation of poverty combined with the rising social inequalities creates on the one hand a new set of opportunities for earning a living, but at the same time is marked by prioritizing immediate needs rather than planning for the future.

However, lack of interest in education does not necessarily mean lack of aspirations. Doubt in the value of formal education is shared by many Cubans, regardless of their material status, as it is not the education and specialized jobs that provide a considerable income but owning a business. Moreover, many people long for material status indicators, such as expensive clothes or shoes rather than formal education. The first time I met Raiza's daughter was when she passed by the house with newly bought shoes for around $50 \mathrm{CUC}^{7}$ (a significant amount

${ }^{6}$...we experienced this also when we were fixing the Stairway [the central part of the settlement], as we did this without any knowledge of construction work, with our hands, I don't know. And at the beginning they would laugh saying "these people are crazy." And after they would join in and they started to prepare the mix [building material], saying "look, this recipe you use is not correct, I will do it for you."

${ }^{7}$ Cuban economy operates on double currency - Peso Cubano or Moneda Nacional (CUP) and Peso convertible (CUC) which value is equivalent to the American Dollar. The exchange rate between CUP 
provided that the official state salary is around $600 \mathrm{CUP}$, equivalent of $25 \mathrm{CUC}$ ). Her appearance was followed by the discussion on shoes and where to get them with a discount. Raiza herself saw the opening of a religious products shop as an opportunity to make a living and contribute to the project, which implies being able to earn more than just to survival income. Engagement in religious communities, either through setting up related businesses or being initiated into them, is also a sign of a seeking ways to improve one's well-being.

Understanding that, the project engages with local leaders in order to promote their initiative - hence Raiza became an important contributor to the project. It also established cooperation with the increasingly popular Abakúa community in the district - los Pocitos is one of its important centers. Abakúa is an exclusively male religion/secret society with traditions stemming from the nineteenth century. It has been and still is associated with criminality and persecuted by $\mathrm{Cu}-$ ban administration regardless of its political ideology (colonial, imperialist, or socialist). It was the Abakúa community that controlled ports in Havana and held considerable economic and political power. Only in recent years have they been officially recognized. The stigma of criminality however remains strongly associated with male dominance and force. Many of the elder members regard these associations as misconception and contrary to Abakúa moral values (Routon, 2005). Notheless, guaperia (aggressive, confrontative macho behavior) is still attributed to the members of the Abakúa community and marginalized neighborhoods in general. Los Pocitos counts with more than ten temples and new ones are being open. Some of the Abakúa leaders in the area expressed their support for the project and lent temple spaces for workshops and other activities, seeing that the project can potentially help with resolving certain issues within the community.

\section{PROYECTOS COMUNITARIOS AS ALTERNATIVES TO DEVELOPMENT IN CUBA}

Regardless of difficulties and challenges faced by project coordinators when engaging with the communities, proyectos comunitarios represent a new approach towards community development in Cuba. Although they are strongly informed by the community engagement practices developed during the revolution, these projects are a product of the changing context of Cuban economy and society. In order to reach their goals and ensure their existence they employ

and CUC is 24 to 1 . The double currency was introduced to limit the circulation of dollars, but in the recent years there have been plans of reuniting the currency and in most of the shops one can use both (contrary to earlier years where in certain shops one could only play in one of the currencies). 
tourist economies as a means of assuring their survival but are at the same time deeply informed by the already existing framework of social initiatives.

The Cuban government, as with Talleres Integrales de Transformación del Barrio, in the course of the last 30 years has been able to recognize the importance of dialogue with local communities and other institutions. This led to a formation of a particular understanding of civil society within an authoritarian state. Rafael Hernandez, a Cuban scholar and important commenter on everyday issues of Cuba, claims that "socialism does not manifest itself only in a political system and an ideological discourse, nor can it develop organically if it does not have roots in civil society" (Hernández, 2003: 29). The government in recent years has increasingly recognized the role of various religious (especially AfroCuban) and other associations such as free Masonry as important actors that represent local communities (Hearn, 2008: 9). According to Margaret E. Crahan (2015), Cuban religious associations often served as voices that animate civil society and as a platform of communication with the government. This approach of the Cuban state also opened doors to receiving funding from international NGOs for social initiatives.

Hearn (2008: 72) underlines that even though certain decentralization and engagement of the non-state actors improved efficiency of social services and allow to identify the needs of the local communities better, it was not followed by sufficient funding and many of the issues remained unanswered. Proyecto Akokán and other recently formed community projects are seeking an alternative to this problem and provide a new outlook on development and responding to community needs through diversifying the sources of funding and seeking them primarily outside of the state. To achieve sustainability, they rely on cuentapropismo, the small enterprises with increasing importance within the Cuban economy whose existence the government allowed and regulated in recent years (Ana \& Lubiński, 2019). But they frame it as experiencia solidaria (solidarity experience), as in the case of Café Oddara which serves as a mechanism of providing revenue to Proyecto Akokán. At the same time, other sources of revenue are actively sought (also by showing their presence with local authorities, as well as looking for grants provided by embassies or international NGOs). Some of them even have gained international recognition in recent years as creative means of helping the communities, thus attracting numerous tourists interested in "giving back."

As such, these new projects are also a response to specific necessities produced by a shift to tourism economies and limited liberalization of the economy that produces new spaces for exercising social solidarity. Their legitimacy 
does not stem from state authorization or they deem it secondary, but from engaging international audiences like tourists, artists, and activists and having them contribute to the project. In order to do so, proyectos comunitiarios develop their own systems of subsistence outside or on the verges of the state apparatus.

In case of Proyecto Akokán the businesses that were providing funding for the activities were guided tours around the community as well as the café located in Michael and Deborah's house that offered dinners for the visitors of the tour. Reliance on tourism is not always a steady investment - with the Trump administration's limitations on travel to Cuba by the United States citizens, the numbers of people taking Michael's tours diminished, as most of them were groups of students from the northern neighbor. This also affected the café as without the tours no one would actually come to eat so far outside of the tourist district. As a consequence, the project leaders would cling to other options such as event catering to maintain income.

In order to achieve more independence, Michael and Deborah aimed to develop the already existing businesses and add another to them that would provide part of their income for the project. At the time, as I already mentioned, Raiza was planning to open a store with religious products and one of the neighbors wanted to open decorative plants shop that would also dedicate part of its income for the project thus becoming a negocio solidario, a solidary business. Deborah explained that all this served to creating a system of leverages to maintain the initiative:

D: La idea sería como crear un círculo, un ciclo, por ejemplo, una vez que nosotros, en la comunidad, el desarrollemos visualmente que creemos, creamos emprendimientos que sea atractiva van a ir clientes, van a ir ya, va ser ya conocida, van a ir clientes y de ahí se puede alimentar también el café y de allí. Es como un círculo que queremos crear. Pero eso sería un poquito más adelante. ${ }^{8}$

Despite the efforts to create a self-sustaining circle, attracting tourism remains one of the principle ideas of funding the project and development of the community - one of the ideas developed during my last stay in Cuba was the activity of painting fronts of the houses within the settlement - engaging students, artists and anyone interested into painting the ornaments on the wall in order to make the settlement more beautiful and attract tourism and more media coverage.

\footnotetext{
${ }^{8}$ The idea would be to create a circle, a cycle. For example, once we, the community create enterprises that will be attractive, they will bring clients, that will come, it [the community] will be already known, the clients will come and this can allow to aliment the café and from that... It's like a circle that we want to create, but this would happen a little later.
} 
The necessity to maintain a business, make a living, and, at the same time, gain revenue for the project undoubtedly raises questions about the redistribution of gains. Several successful projects in Cuba, such as Callejón de Hamel, a small side street that hosts rumba events every week in Habana Centro and has become a must-see tourist attraction. Similarly, certain initiatives in Habana Vieja, have been criticized for not really benefitting their communities, but rather using the solidarity aspect as a publicity stunt to attract tourists and earn money from them. Many members of the religious communities and people involved in community work would underline how Callejón has become more a business that was selling Afro-Cuban religions to tourists than a place of celebrating santería.

In case of Proyecto Akokán and Café Oddara, Michael and Deborah decided to dedicate $30 \%$ of the gains into funding the project, they say however that for now they invest a lot more due to increasing difficulties. From this they pay the workshop providers (who usually come from outside of the community) and other people involved in the project, as well as buy products for the children (such as notebooks, pens etc.).

It is not only financial income that enables the projects to work, contacts with foreigners open doors to more informal ways of exchange as many of the visitors bring school products such as play-doh, crayons, pencils etc. Michael himself mentioned that thanks to creating informal bonds with tourists when sharing meals after the tours, this opened doors to receiving different products. As these are relatively cheap abroad and difficult to obtain in Cuba (both due to their price and accessibility), material gifts brought by tourists constitute another pillar that allows for the sustainability of the project. I believe that this sustainability mechanism resembles similar strategies employed by owners of private business of Cuba that provide business to tourists. On numerous occasions, hosts refer to their guests as part of the family, or even make them padrinos (godfathers) which creates family ties that create an obligation to provide for members of the extended family by bringing products from abroad. Rebecca Ogden (2015) defines this strategy as affective capital, a form of social capital that relies on developing family ties between Cubans and foreigners who visit them that later translate into access to good brought by the visitors from outside of Cuba when they come back to visit - in the form of clothes, mobile phones, and other goods or simply money. The same issues occurred during my previous research about casas particulares where numerous hosts told me about emotional ties they developed with tourists and I experienced them myself - through staying in touch and being asked to bring to Cuba products otherwise unavailable as a sobrino (nephew). These emo- 
tional ties also serve for casa hosts to become mediators of tourists experience and in a way guides for their visitors (Lubiński, 2017: 79).

A similar process happens in case of proyectos comunitarios - although cooperation with community projects does not involve the same amount of affectivity, the project leaders become mediators of an authentic Cuba, one that is hidden far away from the tourist track. The tours offered by projects such as Proyecto Akokán - respond to the growing need of experiential tourism worldwide (Salazar, 2012) where it is not only sightseeing, but engaging and experiencing lives of local communities that is sought by international visitors. This also translates into a need to give back and support the communities through supporting the project which materializes in gifts, financial support and voluntary work provided by the foreigners seeking to support local communities and have a one-of-a-kind experience.

Proyecto Akokán presents thus a new alternative to community development in Cuba. Instead of relying on government initiative, it seeks to foster sustainability through engaging various institutional and community actors so that the project can maintain itself and benefit the community. Reliance on tourism, seeking revenue through embassy and NGO grants, as well as promoting creation of business within and for the neighborhood is thought to allow to respond to the needs that arise from the daily life of the settlement. Again, one of the important parts of this self-sustaining circle is reliance on informal relations that allow for receiving otherwise unavailable goods. This diversity can be seen as a way of managing risk involved in engaging in such projects, but it is also important to note, that none of these sources provides long-term income and sustainability. Diversification is thus a leverage but one that may not necessarily allow for a long duration of the project.

\section{CONCLUSIONS}

Proyecto Akokán presents an alternative to community development in the context of late socialist Cuba that is undergoing increasing tourism-led marketization, but at the same time did not abandon the socialist ideas. The project leaders through recognizing the capacity of community members to create their own infrastructures and strive for their well-being and employ it as a resource that might interest a certain niche of tourism. They also make creative use of already existing tourist strategies, such as reliance on a form of affective capital and using the generated revenue to achieve other goals within the community. However, there seems to be a certain disconnect between community members 
and the project itself that may not necessarily view the project as a way of improving one's well-being which makes it difficult to assess project's impact on the community at such an early stage.

Katherine A. Gordy (2015: 13) views ideology as an everyday practice and claims that "to live an ideology is both to negotiate a world where choices are not entirely determined by that ideology, and also to reconceptualize that ideology as one encounters particular sets of conditions". Similarly, leaders of the project readapt the socialist ideology to tourism-based economies and growing importance of private businesses in Cuba. Proyecto Akokán and other community projects that are beyond the scope of this article are negotiating socialist ethics and values, such as solidarity in the new context. In the end, they rely already existing mechanisms of community engagement such as Talleres Integrales de Transformación del Barrio, while its leaders strive at overcoming difficulties of prior initiatives through alternative ways of sustaining the project. Tourism thus becomes an important resource for conducting the community work, but also in bringing attention to the housing problem in Havana and topics of exclusion and marginalization in Cuba.

\section{REFERENCES}

Ana, R., \& Lubiński, O. (2019). Cuban private entrepreneurship - from periphery to key sector of the economy in tourism-oriented market socialism. Regional Science Policy and Practice, (11), pp. 467-477. https://doi.org/10.1111/rsp3.12154

Anguelovski, I. (2014). Neighborhood as Refuge. Community Reconstruction, Place Remaking and Environmental Justice in the City. Cambridge, United Kingdom: The MIT Press. https://doi.org/10.7551/mitpress/9780262026925.001.0001

Appadurai, A. (2004). The Capacity to Aspire: Culture and Terms of Recognition. In V. Rao, M. Walton (eds.), Culture and Public Action (pp. 59-84). Stanford, CA: Stanford University Press.

Baker, G. (2006). "La Habana Que No Conoces": Cuban Rap and the Social Construction of Urban Space. Ethnomusicology Forum, 15(2), pp. 215-246. https://doi.org/10.1080/17411910600915380

Blum, D. F. (2011). Cuban youth and revolutionary values. Educating the new socialist citizen. Austin: University of Texas Press.

Bowman, K. (2015). Policy choice, social structure, and international tourism in Buenos Aires, Havana and Rio de Janeiro. Latin American Research Review, 50(3), pp. 135-156. https://doi.org/10.1353/lar.2015.0038

Cabezas, A. L. (2004). Between love and money. Sex, tourism, and citizenship in Cuba and the Dominican Republic. Signs, 29(4), pp. 987-1015. https://doi.org/10.1086/382627

Carty, V. (2009). Capitalist Measures within a Socialist model: a Commodity Chains Analysis of the Emerging Cuban Tourism Industry. Canadian Journal of Latin American and Caribbean Studies, 34(67), pp. 163-195. https://doi.org/10.1080/08263663.2009.10816968 
Colantonio, A., \& Potter, R. B. (2006). Urban Tourism and Development in the Socialist State. Havana during the 'Special Period'. Aldershot, United Kingdom: Ashgate.

Coyula, M., \& Hamberg, J. (2005). Understanding Slums. The Case of Havana, Cuba. Cambridge, MA: David Rockefeller Center for Latin American Studies.

Crahan, M. E. (2015). Religion and Civil Society in Cuba, 1959-2013. In P. Brenner et al. (eds.), A Contemporary Cuba Reader. The Revolution under Raúl Castro (pp. 89-98). Lanham, MD: Rowman \& Littlefield.

Duany, J. (2007). Networks, remittances and family restaurants: the Cuban diaspora from a transnational perspective. In A. O'Reilly Herrera (ed.), Cuba. Idea of a nation displaced (pp. 161-175). Albany: State of New York University Press.

Fernandes, S. (2003). Fear of a Black Nation: Local Rappers, Transnational Crossings, and State Power in Contemporary Cuba. Anthropological Quarterly, 76(4), pp. 575-608. https://doi.org/10.1353/anq.2003.0054

Fernández, D. J. (2000). Cuba and the Politics of Passion. Austin: University of Texas Press.

Frederik. L. A. (2005). Cuba's national characters: setting the stage for the Hombre Novísimo. Journal of Latin American Anthropology, 10(2), pp. 401-436. https://doi.org/10.1525/jlat.2005.10.2.401

de la Fuente, A. (2011). Recreating racism. Race and discrimination in Cuba's "Special Period". Socialism and Democracy, (15), pp. 65-91. https://doi.org/10.1080/08854300108428278

Gordy, K. A. (2015). Living Ideology in Cuba. Socialism in Principle and Practice. Ann Arbor: University of Michigan Press. https://doi.org/10.3998/mpub.7327764

Hearn, A. H. (2008). Cuba. Religion, Social Capital, and Development. Durham, NC: Duke University Press. https://doi.org/10.1215/9780822389484

Hernández, R. (2003). Looking at Cuba. Essays on Culture and Civil Society. Gainesville: University Press of Florida.

Hodge, G. D. (2014). „Dangerous” Youth: Tourism Space, Gender Performance, and the Policing of Havana Street Hustlers. The Journal of Latin American and Caribbean Anthropology, 19(3), pp. 441-472. https://doi.org/10.1111/jlca.12104

Klepak, H. (2015). The Revolutionary Armed Forces: Loyalty and Efficiency in the Face of Old and new Challenges. In P. Brenner et al. (eds.), A Contemporary Cuba Reader. The Revolution under Raúl Castro (pp. 73-82). Lanham, MD: Rowman \& Littlefield.

Lievesley, G. (2004). The Cuban Revolution. Past, Present and Future Perspectives. New York, NY: Palgrave Macmillan. https://doi.org/10.1057/9781403943972

Lubiński, O. (2017). Imaginarium państwa. Seksturystyka i oddolne systemy kontroli kontaktów między Kubańczykami a turystami. Zeszyty etnologii wrocławskiej. 1(26), pp. 69-88.

Medina Lasansky, D. (2004). Tourist geographies. Remapping Old Havana. In D. Medina Lasansky, \& B. McLaren (eds.), Architecture and tourism. perception, performance, and place (pp. 165-186). Oxford, United Kingdom: Berg Publishers. https://doi.org/10.5040/9781350057715.ch-009

Ogden, R. (2015). Understanding Cuban Tourism: Affect and Capital in Post-Special Period Cuba (Doctoral dissertation). Manchester, United Kingdom: University of Manchester. 
Premat, A. (2012). Sowing Change. The Making of Havana's Urban Agriculture. Nashville, TN: Vanderbilt University Press.

del Real, P., \& Scarpaci, J. (2011). Barbacoas: Havana's New Inward Frontier. In A. Birkenmaier \& E. Whitfield (eds.): Havana beyond the ruins: Cultural Mappings after 1989 (pp. 5372). Durham, NC: Duke University Press. https://doi.org/10.1215/9780822394426-004

Routon, K. (2005). Unimaginable Homelands? "Africa” and the Abakúa Historical Imagination. Journal of Latin American Anthropology, 10(2), pp. 370-400. https://doi.org/10.1525/jlat.2005.10.2.370

Salazar, N. B. (2012). The Power of Imagination in Transnational Mobilities. Identities: Global Studies in Culture and Power, 18(6), pp. 576-598. https://doi.org/10.1080/1070289X.2011.672859

Segre, R., Coyula, M., \& Scapraci, J. L. (1998). Havana. Two Faces of the Antillean Metropolis. Chichester, United Kingdom: John Wiley \& Sons.

Yurchak, A. (2005). Everything was forever, until it was no more: the last Soviet generation. Princeton, NJ: Princeton University Press. 